\title{
Nitrogen fixation by cyanobacteria stimulates production in Baltic food webs
}

\author{
Agnes M. L. Karlson, Jon Duberg, Nisha H. Motwani, Hedvig Hogfors, \\ Isabell Klawonn, Helle Ploug, Jennie Barthel Svedén, Andrius Garbaras, \\ Brita Sundelin, Susanna Hajdu, Ulf Larsson, Ragnar Elmgren, \\ Elena Gorokhova
}

\begin{abstract}
Filamentous, nitrogen-fixing cyanobacteria form extensive summer blooms in the Baltic Sea. Their ability to fix dissolved $\mathrm{N}_{2}$ allows cyanobacteria to circumvent the general summer nitrogen limitation, while also generating a supply of novel bioavailable nitrogen for the food web. However, the fate of the nitrogen fixed by cyanobacteria remains unresolved, as does its importance for secondary production in the Baltic Sea. Here, we synthesize recent experimental and field studies providing strong empirical evidence that cyanobacterial nitrogen is efficiently assimilated and transferred in Baltic food webs via two major pathways: directly by grazing on fresh or decaying cyanobacteria and indirectly through the uptake by other phytoplankton and microbes of bioavailable nitrogen exuded from cyanobacterial cells. This information is an essential step toward guiding nutrient management to minimize noxious blooms without overly reducing secondary production, and ultimately most probably fish production in the Baltic Sea.
\end{abstract}

Keywords Diazotrophic cyanobacteria - Food webs . Zooplankton grazing $\cdot$ Secondary production $\cdot$ Fish

\section{INTRODUCTION}

\section{Nitrogen-fixing cyanobacteria are natural to the Baltic Sea}

Cyanobacterial blooms are well known in tropical oceans and in freshwater lakes around the world. They also occur in the Baltic Sea, one of the largest areas of brackish water in the

Electronic supplementary material The online version of this article (doi:10.1007/s13280-015-0660-x) contains supplementary material, which is available to authorized users. world, where large blooms of filamentous cyanobacteria appear every summer (Wasmund 1997). These cyanobacteria fix dissolved $\mathrm{N}_{2}$ (diazotrophy), thus circumventing a general nitrogen limitation of the primary production (Granéli et al. 1990), and have been present in the Baltic Sea for c. 7000 years (Bianchi et al. 2000). The prevailing view is that the blooms are a nuisance at best and harmful at worst. Their nitrogen fixation adds large amounts of nitrogen exacerbating eutrophication in the system (Larsson et al. 2001; Gustafsson et al. 2013). Cyanobacterial blooms are often considered to have increased in frequency and magnitude in the Baltic Sea in recent decades (e.g., Kahru and Elmgren 2014). A sequence of events has been proposed to explain this: a higher nutrient load (both $\mathrm{N}$ and $\mathrm{P}$ ) leading to increases in spring phytoplankton production (Gustafsson et al. 2012) and subsequently in sedimentation of organic material, leading to more widespread bottom anoxia in the Baltic (Conley et al. 2011). When sediments turn anoxic, they release stored P (Gunnars and Blomqvist 1997), the primary limiting nutrient for $\mathrm{N}$-fixing cyanobacteria (Walve and Larsson 2007). Little consideration is usually given to conditions promoting control of the bloom initiation, whether by pelagic or benthic grazers.

\section{Cyanobacteria-consumer linkages}

The filamentous diazotrophic cyanobacteria Nodularia spumigena Mertens, Aphanizomenon sp., and Dolichospermum (formerly Anabaena) spp. are the major components of cyanobacterial blooms in the Baltic Sea (Niemi 1979; Wasmund 1997). As most cyanobacteria, they produce numerous bioactive compounds and toxins (e.g., Sivonen and Jones 1999) and these bloom-forming cyanobacteria are therefore considered potentially harmful (Karjalainen et al. 2007). $N$. spumigena is usually of major concern, because it produces the hepatotoxin nodularin (Sivonen and Jones 1999), 
which makes up c. $90 \%$ of cyano-hepatotoxins in the Baltic (Kankaanpää et al. 2009) and is detectable throughout the food web (e.g., Karjalainen et al. 2007). Baltic strains of Dolichospermum spp. produce microcystins, likewise hepatotoxins, whereas no such toxin has been reported in Baltic strains of Aphanizomenon (El-Shehawy et al. 2012).

Today, nutrient management decisions are based on the assumption that production of filamentous toxin-producing cyanobacteria cannot be efficiently utilized by grazers (Elmgren and Larsson 2001) and thus do not contribute to fish production (but see Hansson et al. 2007). Evidence is, however, accumulating that these cyanobacteria are eaten by many grazers, suspension-feeders, and deposit-feeders, often with beneficial effects on their growth and reproduction. In line with this, field studies show that organic matter and bioavailable nitrogen produced by these cyanobacteria are incorporated by pelagic, littoral, and benthic food webs (e.g., Rolff 2000; Karlson et al. 2014; Lesutiene et al. 2014), challenging the view that cyanobacteria do not contribute to secondary production. Moreover, grazing on toxic cyanobacteria is species-specific and influenced by many factors (e.g., toxin concentrations and availability of other prey), with concomitant feed-back effects on toxin production (Gorokhova and Engström-Öst 2009; Engström-Öst et al. 2011). Therefore, changes in the relative abundance of grazers may alter the composition and toxicity of the cyanobacterial assemblages. Also, benthic fauna may influence the initiation and species composition of the blooms, since Dolichospermum spp. and to some extent also N. spumigena depend on recruitment from benthic resting stages, akinetes, which are deposited in sediments after the bloom (Suikkanen et al. 2010) and can be affected by deposit-feeders (Karlson et al. 2012).

This review synthesizes recent studies addressing utilization of cyanobacterial production in pelagic and benthic food webs that collectively provide strong evidence that cyanobacterial nitrogen is efficiently assimilated and transferred in Baltic food webs (Fig. 1). To avoid overly reducing secondary production and prey availability for fish, quantification of these trophic pathways is desirable for predicting effects of nutrient reduction aiming to reduce cyanobacterial blooms.

\section{BIOGEOCHEMICAL ROLE OF CYANOBACTERIA IN THE BALTIC SEA}

\section{Nitrogen fixation as a source of bioavailable $\mathbf{N}$ in the ecosystem}

In summer, the Baltic Sea proper is characterized by a thermocline at 10-20 $\mathrm{m}$ depth and a permanent halocline at $60-70 \mathrm{~m}$ that limits water mixing. Nutrients regenerated above the thermocline are immediately available for primary producers, while those regenerated below the thermocline become available in the upper mixed layer only through wind-induced mixing and upwelling. The input of new bioavailable $\mathrm{N}$ through $\mathrm{N}_{2}$-fixation (Table $\mathrm{S} 1$ in Supplementary Material) is concentrated to the summer. A recent study based on multiple approaches to determine new production in the Baltic proper estimated that $\mathrm{N}_{2}$ fixation provides $20-45 \%$ of the yearly average new production, while external inputs of $\mathrm{NO}_{2}{ }^{-}$and $\mathrm{NO}_{3}{ }^{-}$provide $>50 \%$ (Gustafsson et al. 2013), which implies a yearly $\mathrm{N}_{2}$-fixation of 100-200 mmol N m${ }^{-2}$ year $^{-1}$ (Table S1).

\section{Estimates of $\mathbf{N}$ transfer from diazotrophic cyanobacteria to other primary producers}

Baltic Sea Aphanizomenon sp. and N. spumigena directly release on average $20-35 \%$ of their fixed $\mathrm{N}$ as ammonium, which is then used by other primary producers, e.g., picocyanobacteria, as shown by various approaches including ${ }^{13} \mathrm{C}$ and ${ }^{15} \mathrm{~N}$ tracers (Ohlendieck et al. 2000; Stal et al. 2003; Ploug et al. 2011). Recently, nanoscale secondary ion mass spectrometry (nanoSIMS) has made it possible to measure the $\mathrm{N}$ - and $\mathrm{C}$-fixing activity of individual cells in mixed populations of phytoplankton and microbes. While it has been suggested that Baltic Sea picocyanobacteria may fix $\mathrm{N}_{2}$ (Wasmund et al. 2001), nanoSIMS-based analysis demonstrated that Baltic picocyanobacteria do not fix $\mathrm{N}$, but use $\mathrm{NH}_{4}{ }^{+}$released from filamentous $\mathrm{N}_{2}$-fixing cyanobacteria. In control incubations, cells $<5 \mu \mathrm{m}$ showed high ${ }^{13} \mathrm{C}$ assimilation, but no ${ }^{15} \mathrm{~N}_{2}$-fixation. However, when heterocyst-bearing filamentous cyanobacteria were present, the ${ }^{15} \mathrm{~N}$ label was rapidly transferred to picocyanobacteria, diatoms, and zooplankton (Adam et al., unpublished). Hence, these $\mathrm{N}$-fixing cyanobacteria supply bioavailable $\mathrm{N}$ to the rest of the plankton community (Fig. S1).

\section{Sedimentation of cyanobacteria and fixed nitrogen}

Sediment-trap measurements indicate that little of the cyanobacteria blooms reach the bottom (Bianchi et al. 2002). The gas vacuoles that make filamentous cyanobacteria buoyant supposedly lead to decaying filaments being efficiently remineralized by microbes in the water column (Sellner 1997). However, comparison of different methods for measuring vertical fluxes of particular organic carbon and nitrogen has shown that the sinking flux of organic matter to the sediments in the Baltic Proper has likely been underestimated (Gustafsson et al. 2013). Based on this, the PON sedimentation in May-September, representing most of the spring bloom and the whole summer bloom, was calculated to be $240 \mathrm{mmol} \mathrm{N} \mathrm{m}^{-2}$ year $^{-1}$ (J. Gelting, pers. comm). Locally, in shallow, coastal areas where winds concentrate the blooms, an even larger sedimentation is likely. 


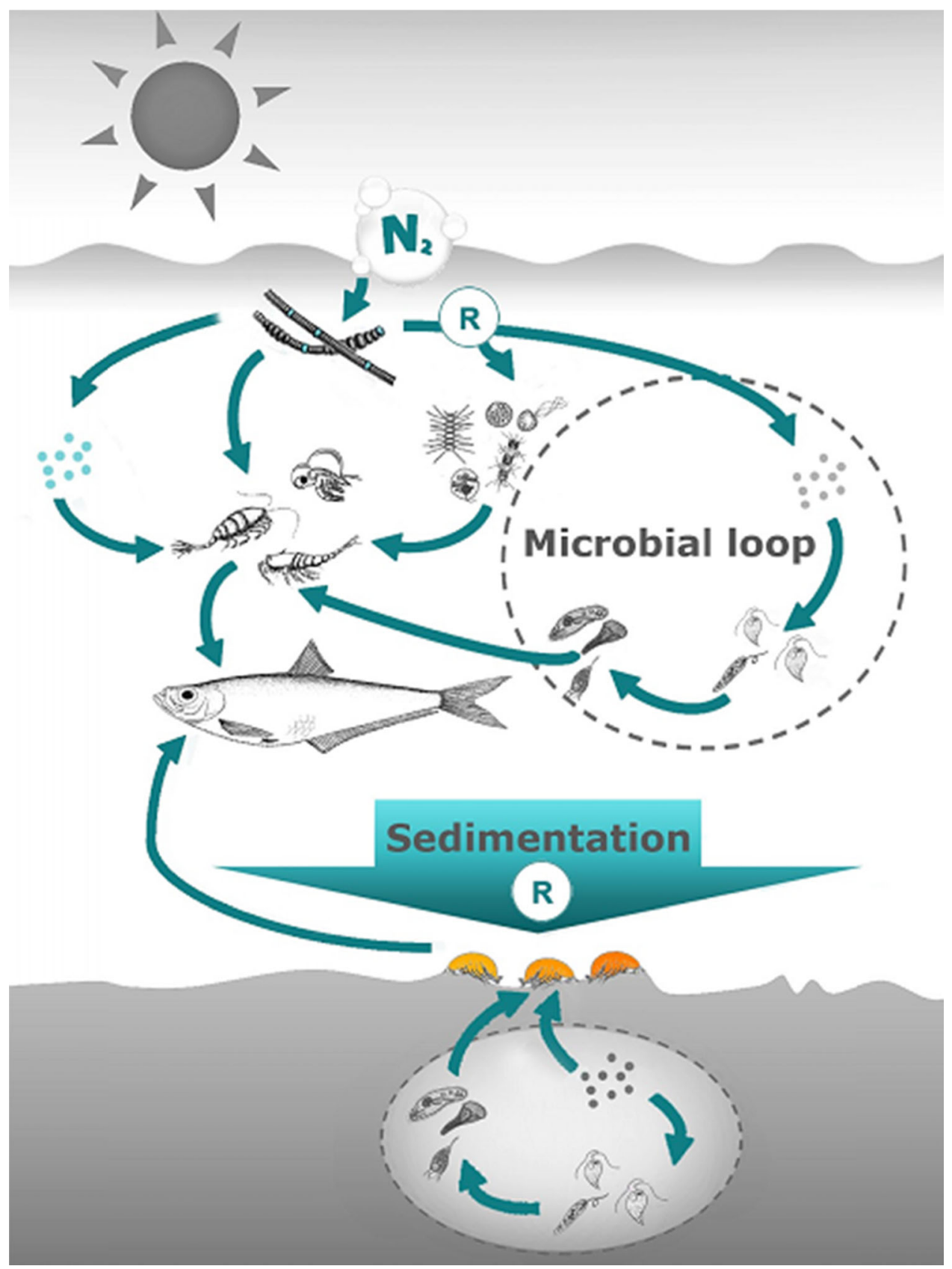

Fig. 1 Bloom-forming diazotrophic cyanobacteria stimulating secondary production in the Baltic Sea. By fixing dissolved $\mathrm{N}_{2}$, these cyanobacteria are important suppliers of bioavailable nitrogen to the pelagic and benthic food webs that support fish production. The bioavailable nitrogen enters the food web through direct grazing on fresh or decaying filamentous cyanobacteria by various invertebrates and by cyanobacterial cells releasing bioavailable nitrogen (denoted by $R$ ) that is taken up by other phytoplankton and microbes, which are in turn eaten by animals in the water column and sediments

Simultaneous measurements of sinking rate and respiration on N. spumigena aggregates in the Baltic Sea show that sedimentation during decay is rapid, increasing from 4 to $44 \mathrm{~m} \mathrm{day}^{-1}$ within $12 \mathrm{~h}$ (Ploug 2008). A high settling flux of Baltic Aphanizomenon sp. has occasionally been recorded also with sediment traps (Tallberg and Heiskanen 1998). Other evidences of substantial input of $\mathrm{N}$-fixing cyanobacteria to Baltic sediments include the characteristic cyanobacterial isotope signatures (Bianchi et al. 2000), cyanotoxins (Kankaanpää et al. 2009), and cyanopigments (Bianchi et al. 2000), as well as akinetes (Suikkanen et al. 2010) in sediments. Pigment analysis suggests that also unicellular cyanobacteria sink out (Bianchi et al. 2002). Thus, sedimentation of cyanobacteria and detritus derived from them supplies organic matter to benthic communities. 


\section{TROPHIC TRANSFER OF DIAZOTROPHIC NITROGEN TO PELAGIC AND BENTHIC CONSUMERS}

\section{Tracking transfer of cyanobacterial nitrogen in food webs}

The large variety of transfer pathways and turnover rates in food webs makes it hard to quantify the flow of bioavailable $\mathrm{N}$ from primary producers to top consumers. However, use of stable isotope analysis (SIA), cyanotoxins, pigments,
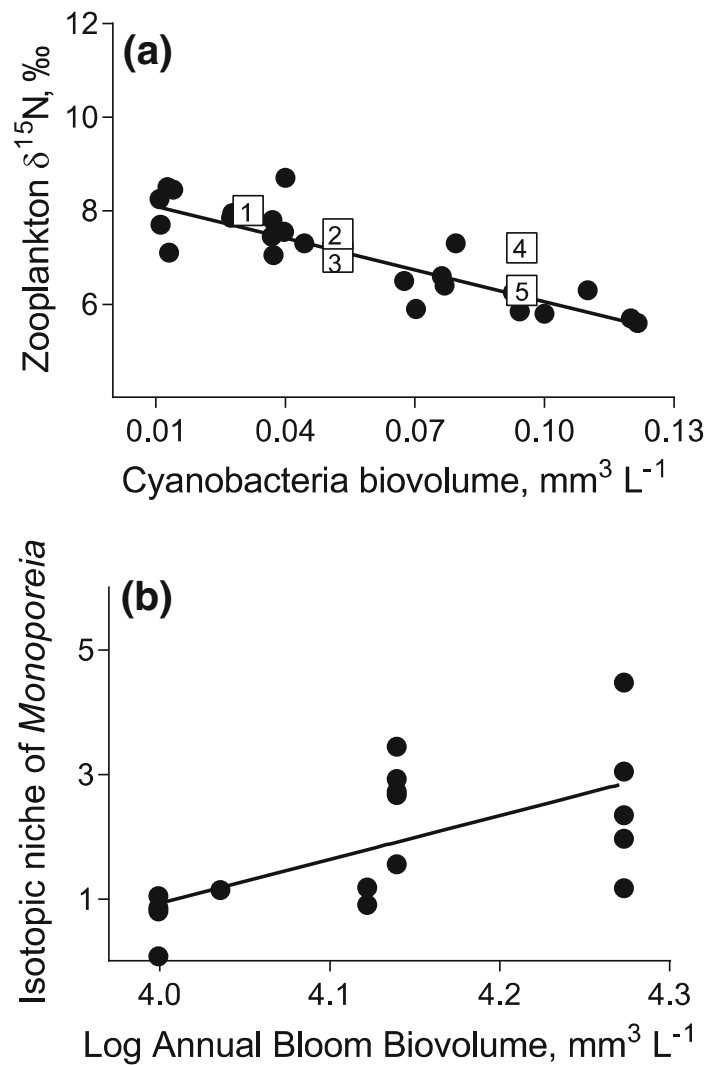

Fig. $2 \delta^{15} \mathrm{~N}$ and isotopic niche in pelagic and benthic consumers in the northern Baltic proper as a function of cyanobacterial biomass. a $\delta^{15} \mathrm{~N}$ in zooplankton (copepods and cladocerans, filled circles) decreases significantly with increasing mean cyanobacteria biovolume $\left(\mathrm{mm}^{3} \mathrm{1}^{-1}\right)$ indicating uptake of diazotrophic nitrogen by zooplankton. Line indicates the trend. Data for June-August, 1976-2010, Askö area, station B1; see Appendix S1 for details. Published data on $\delta^{15} \mathrm{~N}$ in crustacean zooplankton in summer (open squares) support the trend; numbers inside the squares indicate the study ( 1 Hansson et al. 1997; 2 Rolff and Elmgren 2000; 3 Rolff 2000; 4 Holliland et al. 2012; and 5 Hansen et al. 2012). b Diet diversity measured as isotopic niche size in the deposit-feeding amphipod Monoporeia affinis in October increases significantly with annual bloom biovolume calculated as the area under the curve for plots of cyanobacteria biovolume over time (May to September, 2000-2011, Himmerfjärden Bay, see Appendix S2 for details). Line indicates the trend. Larger values of isotopic niche estimated as convex hull area suggest larger trophic diversity and greater dietary breadth. a Spearman $r=-0.85, p<0.001$; b Spearman $r=-0.79$, $p<0.001$ fatty acids (FAs), and molecular diet analysis has convincingly shown that many pelagic and benthic animals consume and assimilate diazotrophic nitrogen. In addition to the bulk SIA, compound-specific SIA of amino acids has been used to evaluate the transfer of diazotrophic $\mathrm{N}$ in food webs because it provides an internal reference to the $\delta^{15} \mathrm{~N}$ of the primary producers, a particularly useful property when the baseline varies due to temporal variation in $\mathrm{N}$-fixation (Loick-Wilde et al. 2012).

Studies tracing source and fate of $\mathrm{N}$ in aquatic food webs rely largely on the use of ${ }^{15} \mathrm{~N}$. Diazotrophic cyanobacteria that use $\mathrm{N}_{2}$ gas to satisfy their nitrogen requirements have $\delta^{15} \mathrm{~N}$ values between -1 and $-2 \%$ (e.g., Rolff 2000). This isotopic signature can be used to track the flow of diazotrophic $\mathrm{N}$ through the food web (Figs. 2, $3)$. Early studies tracked the flow of cyanobacteria-derived $\mathrm{N}$ through pelagic primary and secondary trophic levels in the Baltic Sea using the depleted ${ }^{15} \mathrm{~N}$-signal (Meyer-Harms et al. 1999; Rolff 2000). Later studies show that many invertebrates and fish become ${ }^{15} \mathrm{~N}$ depleted during cyanobacterial blooms, indicating transfer of diazotrophic $\mathrm{N}$ in the food web (Fig. 3a). This effect of cyanobacteria on $\delta^{15} \mathrm{~N}$ values in benthic and pelagic consumers is a combined result of direct consumption of cyanobacteria, secondary consumption of fixed $\mathrm{N}$ via microbial food webs, and direct consumption of non-diazotrophic phytoplankton that have taken up $\mathrm{N}$ exuded by diazotrophs. Therefore, the observed correlation between $\delta^{15} \mathrm{~N}$ in a primary consumer and abundance of filamentous cyanobacteria (Fig. 2a) does not prove direct feeding, but may also result from secondary transfer via multiple trophic pathways.

\section{Evidence of direct grazing from molecular diet analysis}

Gut content provides direct evidence of trophic linkage. For relatively large consumers, such as fish and mysids, gut content analysis is the classic method for diet analysis. Recently, molecular diet analysis has made it feasible to identify and quantify Baltic cyanobacteria in the gut of consumers as small as nauplii and rotifers (N. spumigena: Gorokhova 2009; Engström-Öst et al. 2011; Synechococcus: Motwani and Gorokhova 2013), providing in situ data on direct cyanobacteria grazing by zooplankton. This approach uses the polymerase chain reaction (PCR) and species- or groupspecific primers and DNA sequencing to identify prey DNA in the gut of the consumer. Using this method (Fig. S2), $N$. spumigena was found to be a common food for mysids (c. $58 \%$ of population; Gorokhova 2009) and copepods (nearly $100 \%$; Gorokhova and Engström-Öst 2009). Moreover, mysids digest cyanobacteria, as indicated by lower yield of cyanobacterial DNA in their feces than in the stomach bolus (Gorokhova 2009). When bioavailable with SIA, a decrease 


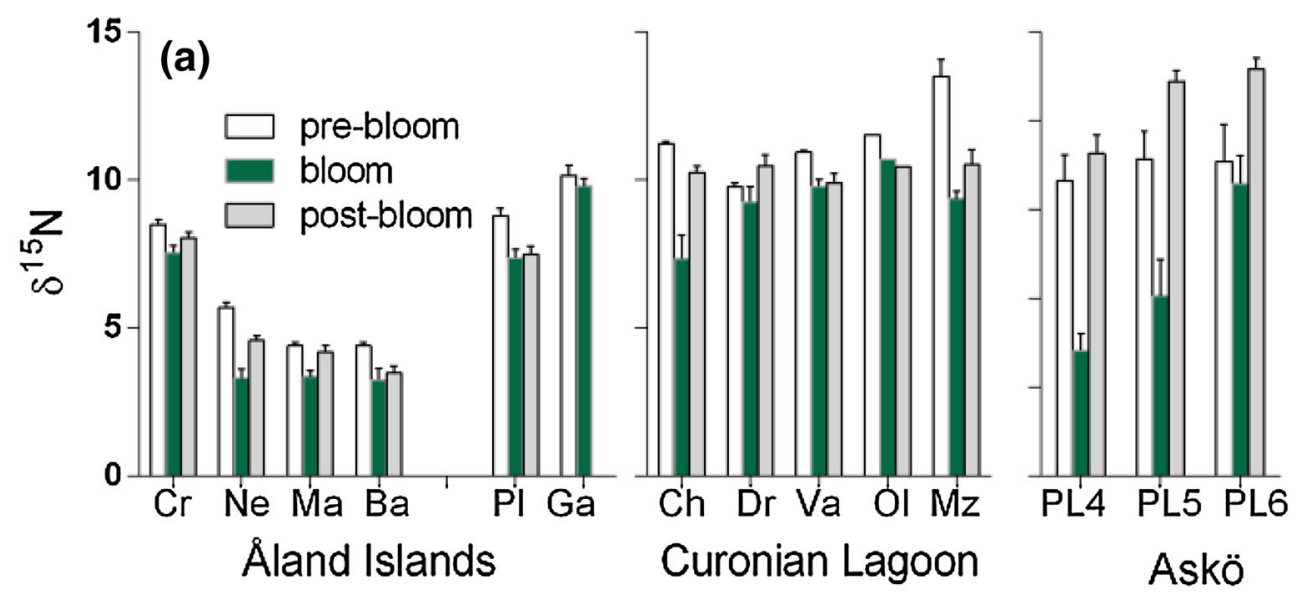

\section{Zooplankton size classes}

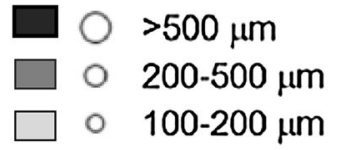

\section{Macrozoobenthos species \\ 图 Monoporeia affinis \\ Macoma balthica}

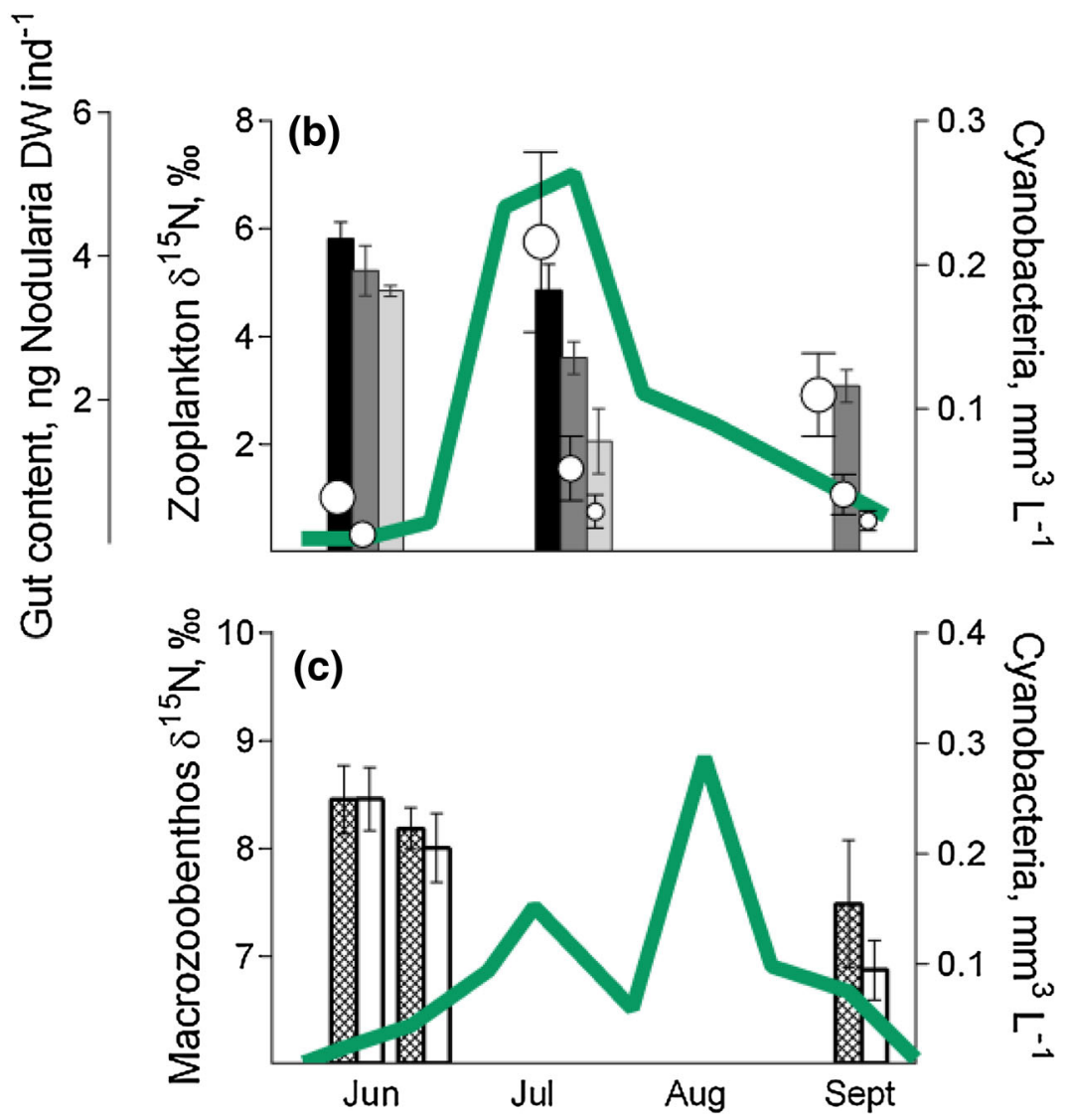

Fig. 3 Uptake of cyanobacteria-fixed nitrogen by pelagic and benthic consumers inferred from seasonal changes in their $\delta^{15} \mathrm{~N}$ values and stomach content analysis in relation to the cyanobacterial bloom in different areas of the Baltic Sea. $\mathbf{a} \delta^{15} \mathrm{~N}$ (mean \pm SD) in invertebrates and fish from three coastal areas: Åland Islands (Nordström et al. 2009), Curonian Lagoon (Lesutiene et al. 2014), and Askö area (Rolff 2000), in relation to the cyanobacteria bloom. Invertebrate species and groups: Cr Crangon crangon; Ne Nereis diversicolor; Ma Macoma balthica; Ba Bathyporeia pilosa; Ch Chironomidae; Dr Dreissena polymorpha; Va Valvata; Ol Oligochaeta; Mz mesozooplankton; PL4 zooplankton, size 100-200 $\mu \mathrm{m}$ (nauplii, rotifers, ciliates); PL5 zooplankton, size 200-500 $\mu \mathrm{m}$ (copepodites, cladocerans); and PL6 zooplankton, size $>500 \mu \mathrm{m}$ (adult copepods). Fish: Pl Platichthys flesus and Ga Gasterosteus aculeatus; $\mathbf{b} \delta^{15} \mathrm{~N}$ values of zooplankton (bars, primary $Y$-axis on the left side; mean $\pm \mathrm{SD}, n>3$ ) and grazing on cyanobacteria derived from qPCR-based estimates of $N$. spumigena abundance in zooplankton stomachs (circles; secondary $Y$-axis on the left side; mean $\pm \mathrm{SD}, n>4$ ) sampled throughout cyanobacteria bloom (green line) in the open sea (Landsort Deep, station BY31; year 2011; Motwani 2015; see Appendix S3). c $\delta^{15} \mathrm{~N}$ values in deposit-feeders (mean $\pm \mathrm{SD}, n>10$ ) sampled before and after a cyanobacteria bloom (green line) in a coastal area (Askö, station B1; year 2010; modified from Karlson et al. (2014) 
in $\delta^{15} \mathrm{~N}$ signal was observed in planktonic grazers when cyanobacteria quantity in their stomachs increases (Fig. 3b), implicating direct grazing as an important pathway. Grazing on cyanobacteria is not unique to the Baltic Sea; qPCR analysis has shown that freshwater zooplankton eat toxic cyanobacteria both in bloom (Sotton et al. 2014) and nonbloom (winter) conditions (Oberholster et al. 2006).

A qPCR assay is also available for Synechococcus, a large picocyanobacterial clade contributing up to half the summer phytoplankton biomass in the offshore Baltic Sea (Hajdu et al. 2007). With small size and high growth rate, picocyanobacteria are most likely to benefit from diazotroph exudates supplying N (Ploug et al. 2011). All main Baltic zooplankton groups feed on Synechococcus (8-10\% of the gut content in copepods and $15-30 \%$ in cladocerans, rotifers, and nauplii; Motwani and Gorokhova 2013). This direct metazooplankton grazing on non-diazotrophic picoautotrophs, fueled by diazotroph exudates, is thus potentially an important source of $\mathrm{N}$ for zooplankton in summer (Fig. 1).

\section{Fatty acids and toxins}

Cyanobacteria-derived material can also be distinguished by the presence and ratios of particular FAs (Ahlgren et al. 1992), and Baltic copepods assimilate cyanobacterial FAs (Peters et al. 2006). Finally, cyanotoxins in consumer tissues indicate feeding on cyanobacteria (Karjalainen et al. 2006; Sipiä et al. 2006; Mazur-Marzec et al. 2007). However, such linkages are uncertain, since we do not know how the toxin reached the consumer (see review in Karjalainen et al. 2007), and because animals (and their microbes) vary in their capacity to metabolize toxins (Karjalainen et al. 2006).

Combined approaches are required to estimate the relative importance of various pathways of $\mathrm{N}$ incorporation in food webs. For example, by combining analysis of cyanobacteriaspecific pigments and $\delta^{15} \mathrm{~N}$ in copepods, Meyer-Harms et al. (1999) showed that copepods eat filamentous cyanobacteria and assimilate fixed N. Combining SIA with PCR-, FA-, or pigment-based methods for prey identification can facilitate the use of mixing models for diet analysis by justifying inclusion of specific prey in models that estimate diet composition (Gorokhova and Lehtiniemi 2007).

\section{TRANSLATING CYANOBACTERIA-DRIVEN PRIMARY PRODUCTION INTO SECONDARY PRODUCTION}

\section{Feeding on cyanobacteria can increase reproductive output and somatic growth in consumers}

Like other filamentous toxin-producing cyanobacteria, Baltic cyanobacteria are generally considered to be inadequate as food for grazers due to their (i) toxins and bioactive compounds that hamper digestion, (ii) poor manageability, and (iii) low nutritional value due to low content of essential components like polyunsaturated FAs and sterols (e.g., Gulati and DeMott 1997). However, cyanobacteria are a rich source of $\mathrm{N}$ and $\mathrm{P}$ (Walve and Larsson 2007) and essential amino acids (Ahlgren et al. 1992; Loick-Wilde et al. 2012) as well as some vitamins (Prasanna et al. 2010) and antioxidants (Pandey and Pandey 2009). Also, cyanobacterial filaments host a rich community of associated microorganisms (Hoppe 1981; Ploug et al. 2011) that should increase their nutritional value.

Although Baltic zooplankton have been reported to avoid ingesting filamentous cyanobacteria, there are also reports that they feed on cyanobacteria, in the laboratory, in mesocosms, and in the field (reviewed in Hogfors et al. 2014; summarized in Fig. S2). In situ, zooplankton prefer other phytoplankton, but feed opportunistically on cyanobacteria (Meyer-Harms et al. 1999).

Short-term laboratory studies reporting negative effects of toxic $N$. spumigena on zooplankton survival and reproduction have used cyanobacteria cultures, often as the single food source (e.g., Engström et al. 2000, 2001). However, a meta-analysis of laboratory experiments on the effects of cyanobacteria on zooplankton population growth across genera and species showed that $73 \%$ of species maintained positive growth when fed a diet containing cyanobacteria, even though cyanobacteria were a poorer food than green algae and/or flagellates alone for half of the species tested (Tillmanns et al. 2008). Moreover, adding other algal species of sufficient nutritional quality to a mono-diet of cyanobacteria can reduce the negative effects (Reinikainen et al. 1994).

In line with this, studies simulating ambient feeding conditions during a cyanobacterial bloom reported that Baltic copepods can ingest cyanobacteria without negative effects on survival, egg production, or hatching success (Fig. 4). Moreover, fitness-related parameters responded differently to cyanobacteria addition. For example, addition of $N$. spumigena to a mono-diet of green alga reduced egg production, but improved oxidative balance, egg viability, and early naupliar development in Acartia bifilosa (Vehmaa et al. 2013). By contrast, increasing concentrations of $N$. spumigena in the copepod diet had no effect on egg hatching success, although there was a negative relationship between copepod gross growth efficiency and accumulated nodularin (Kozlowsky-Suzuki et al. 2003). The overall conclusion of both studies was that N. spumigena is not harmful to copepods if an alternative food is also available. Since N-sufficient diets were used in the experiments, the extra supply of $\mathrm{N}$ cannot explain these effects; instead, they may be related to complementary 


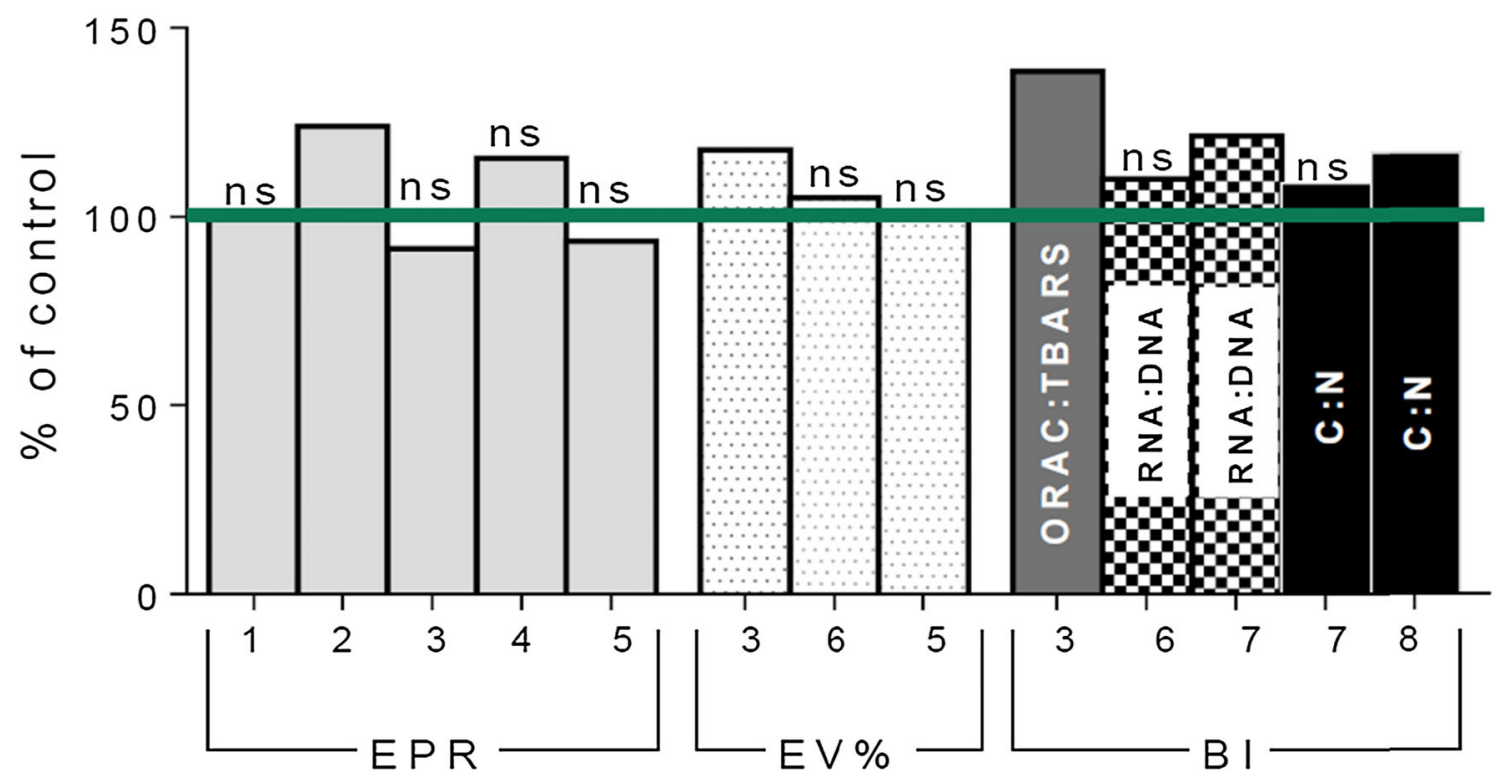

Fig. 4 Effects of cyanobacteria on fitness-related traits ( $E P R$ egg production rate and $E V \%$ egg viability) and growth-related biochemical indices (BI) in Baltic copepods (Acartia bifilosa, A. tonsa, and Eurytemora affinis; studies 1-4, and 6 ) and amphipods (Monoporeia affinis; studies 5 and 7-8). Only studies that used feeding conditions with cyanobacteria concentrations approximating those during summer bloom in the Baltic Sea and animals pre-exposed to the bloom are presented. Effects are expressed as \% deviation from the control (non-cyanobacterial diet, green line); non-significant effects $(p>0.05)$ are marked $n s$. Numbers on the X-axis indicate study reporting the effect; 1 Schmidt and Jonasdóttir (1997), 2 Koski et al. (2002), 3 Vehmaa et al. (2013), 4 Schmidt et al. (2002), 5 Wiklund et al. (2008), 6 Hogfors et al. (2011), 7 Karlson (unpubl.) (see Appendix S4), and 8 Karlson et al. (2014). The biochemical indices of growth status: ORAC:TBARS ratio [ORAC total antioxidative status measured as oxygen radical absorbance capacity and TBARS lipid peroxidation measured as production of thiobarbituric acid reactive substances; (Vehmaa et al. 2013)] is a proxy for oxidative status, RNA:DNA ratio is a proxy for protein synthetic capacity, and the C:N ratio reflects lipid storage in amphipods

nutrients or microelements, present in $N$. spumigena but missing from the alternative food (Hogfors et al. 2014). In bloom conditions, the positive effects on naupliar development might be enhanced by picoplankton, stimulated by exudates, and efficiently used by nauplii, especially when high-quality phytoplankton are scarce (Motwani and Gorokhova 2013). Regardless of the mechanisms, the positive effect on egg and naupliar development should improve copepod recruitment and, ultimately, population growth, although detecting these effects at high fish predation is challenging.

In experiments with benthic deposit-feeders, cyanobacteria are generally growth neutral, whereas sediment supplied with diatoms supports rapid growth (Karlson et al. 2008; Nascimento et al. 2009; Karlson and Mozuraitis 2011). Depositfeeders fed Aphanizomenon and $N$. spumigena incorporated large quantities of cyanobacterial $\mathrm{C}$ and $\mathrm{N}$, without increased mortality (Karlson et al. 2008; Nascimento et al. 2008; Karlson and Mozuraitis 2011). Short-term experiments with relatively slow-growing animals may underestimate the value of cyanobacteria as food over longer times. In field and experimental studies mimicking in situ conditions, bivalves and amphipods fed cyanobacteria perform better than when starved (Basen et al. 2012; Gergs et al. 2014; Fig. 4), and the nutritional quality of cyanobacterial matter improves with time through toxin breakdown by animals (Svensen et al. 2005) or as a result of trophic upgrading by bacteria (MazurMarzec et al. 2009) or metazoans (Basen et al. 2013). Microbes contributing to such trophic upgrading should also transfer diazotrophic $\mathrm{N}$ to deposit-feeders (Fig. 1).

To study the effect of cyanobacterial food on a benthic deposit-feeder community, Karlson et al. (2014) used an isotope niche approach based on SIA (Layman et al. 2007). Settling material from the cyanobacterial bloom expanded the isotopic niches in deposit-feeders reflecting their trophic niche increase (Fig. 2b), with concomitant positive effects on body condition in some species, and decreased food competition (Karlson et al. 2014; Fig. 4). Moreover, species composition of the benthic community and cyanobacterial assemblages influenced the trophic transfer (Nascimento et al. 2008; Karlson et al. 2010), often with higher uptake for Aphanizomenon than for N. spumigena (amphipods: Karlson et al. 2008; mysids: Engström et al. 2001; cladocerans: Wannicke et al. 2013).

\section{Consequences for food web efficiency and productivity in the Baltic Sea}

Application of various tracers demonstrates that biologically fixed cyanobacterial $\mathrm{N}$ is incorporated by multiple trophic 
levels in the Baltic, the Gulf of Mexico (Dorado et al. 2012), and estuaries in Australia (Woodland et al. 2013). Baltic cyanobacteria rapidly build up biomass in early summer, when the pelagic food web becomes N-limited and when zooplankton production is of particular importance for the newly hatched larvae of many fish species (Hansson et al. 2007; Fig. 5). According to our current understanding of Baltic trophodynamics, supported by estimates of diazotrophy in pelagic and littoral food webs (Fig. 3), diazotrophic N enters food webs already at bloom initiation and is transferred via multiple pathways to zooplankton and benthos and, ultimately, to fish. Moreover, deposit-feeders below the photic zone are critically dependent on settling phytoplankton for growth and exhaust much of the spring bloom input within a few months (Uitto and Sarvala 1991). While the cyanobacteria are nutritionally inferior to the diatom-rich spring bloom, they are still valuable as a supplementary food during summer, and sedimentation of cyanobacteria might provide a crucial food input to benthos before winter starvation (Karlson et al. 2008; Nascimento et al. 2008). Thus, diazotrophic $\mathrm{N}$ supports production of zooplankton and benthos in this $\mathrm{N}$-limited system during summer.

Estimating the quantitative contribution of fixed $\mathrm{N}$ to the secondary production is, however, difficult and requires some as yet untested assumptions (e.g., of number of trophic transfers, isotopic fractionation, and equilibrium time). Estimates vary from $5-10 \%$ for deposit-feeders in coastal areas of the northern Baltic Proper (Karlson et al. 2010) to $50-80 \%$ in planktonic and benthic invertebrates in the shallow Curonian Lagoon (Lesutiene et al. 2014). Mesocosm-based measurements suggest that diazotrophic bloom contributes $23-45 \%$ to mesozooplankton biomass (Sommer et al. 2006). Moreover, using ${ }^{15} \mathrm{~N}$-labeled cyanobacteria, Wannicke et al. (2013) estimated that diazotrophic $\mathrm{N}$ contributed $27 \%$ to mesozooplankton production, one-third from direct grazing on filamentous cyanobacteria and the rest via the microbial loop (Fig. 1). The exact pathway can make a large difference when calculating cyanobacteria contribution to secondary production, because each added trophic step lowers the trophic efficiency. Since trophic efficiency is, therefore, an order of magnitude higher in a phytoplankton-based food web than in one based on bacteria (Berglund et al. 2007), the isotopic signal mediated by phytoplankton will be stronger and less affected by metabolic losses than in the microbial loop with its multiple trophic transfers.

The plausible positive effects of diazotrophic $\mathrm{N}$ on secondary production in the Baltic Sea, including the temporal coupling between nitrogen fixation, zooplankton dynamics, and the peak in zooplankton consumption by clupeids, suggest that this $\mathrm{N}$ input is important for fish production (Hansson et al. 2007). Since herring and other pelagic fish are food limited at this time of the year (Arrhenius and Hansson
1993), any increase in prey availability will ultimately translate into increased fish production, as also indicated by $\delta^{15} \mathrm{~N}$ signal in some fish species following the bloom (Nordström et al. 2009; Lesutiene et al. 2014). In freshwater, application of FA markers has provided compelling evidence that toxic cyanobacterial blooms provide juvenile perch with components of high nutritional value (Perga et al. 2013). The authors concluded that the cyanobacterial bloom could be regarded as a significant dietary bonus for juvenile fish at a critical time of the year. Although the duration of this effect might be relatively short, it occurs at a crucial time for larval growth and hence fish recruitment.

While cyanotoxins are potentially harmful (particularly to vertebrates) and cyanobacterial blooms may decrease fish survival and fitness, either directly (i.e., acute toxicity) or indirectly (e.g., toxin transfer via prey, bloom-induced turbidity reducing prey capture; Karjalainen et al. 2007; Persson et al. 2011), more field studies are needed to understand the net effect of cyanobacterial blooms on fish in the Baltic Sea. Specifically, the likely benefits of diazotrophic $\mathrm{N}$ supporting nutrition and survival of larvae and juveniles need to be evaluated in relation to potential toxicity-induced losses in fish production. Similarly, if the benefits of ingesting cyanobacteria are greater than the costs associated with detoxification, selection will favour grazers with greater capacity to consume cyanobacteria. As cyanobacteria blooms are often predicted to increase in response to climate change (Paerl and Fulton 2006), we may expect an increasing evolutionary pressure on all Baltic food web components to cope with cyanobacteria in the system, a higher degree of co-existence for consumers and cyanobacteria and a more efficient channeling of cyanobacteria biomass to the secondary production. This is an exciting field requiring joint efforts of ecologists and evolutionary biologists.

\section{IMPLICATIONS FOR ADAPTIVE MANAGEMENT OF BALTIC SEA ECOSYSTEMS}

\section{Knowledge gaps in our understanding of cyanobacteria importance for Baltic productivity}

The main challenge for management of cyanobacteria blooms in the Baltic Sea is to establish ecological threshold levels for the occurrence of the dominant cyanobacteria, where the beneficial effects on secondary and tertiary productivity override detrimental effects on growth and reproduction of pelagic and benthic animals as well as negative effects on tourism and recreation. Quantifying the contribution of cyanobacterial blooms to production of zooplankton, benthos, and fish is critical for determining these thresholds. Future studies also need to consider other 

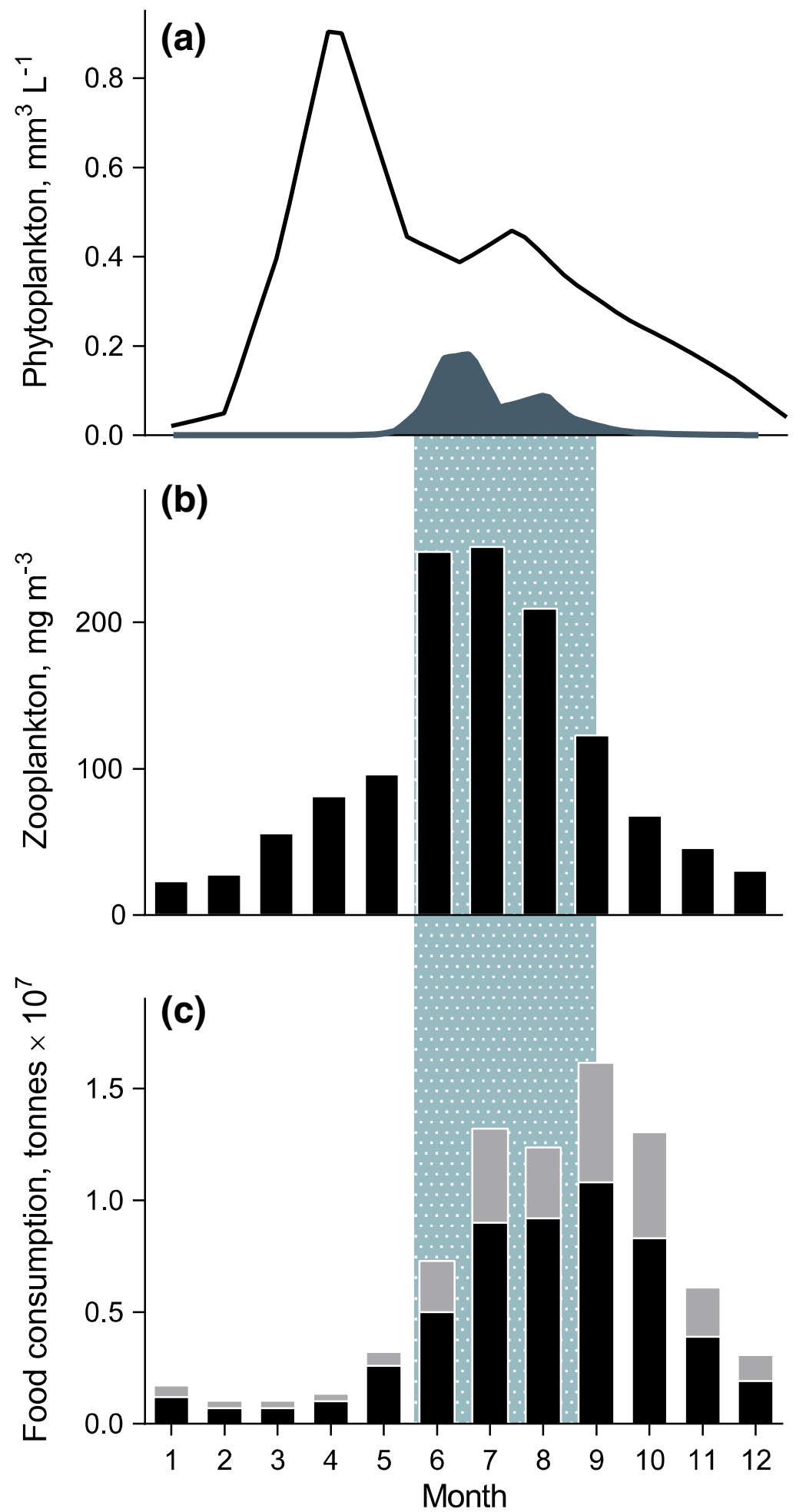

Fig. 5 Seasonal development of a phytoplankton biomass, including cyanobacteria, b zooplankton biomass, and $\mathbf{c}$ estimated food consumption by zooplanktivorous fish in the Baltic Sea. In June-September, cyanobacteria contribute substantially to the phytoplankton communities, which coincides with the highest zooplankton stocks, and the highest food consumption by fish. The phytoplankton and zooplankton data are long-term means (1992-2011) for the Askö area (station B1), and fish estimated food consumption data are from Arrhenius and Hansson (1993). See Appendix S1 for details on plankton sampling and analysis. a Black line total phytoplankton, grey shading cyanobacteria; c grey shading sprat, black shading herring 
ecologically important factors, such as climate-related changes in physics, chemistry, and phytoplankton (e.g., Vehmaa et al. 2013; Kahru and Elmgren 2014), combined effects of cyanobacterial toxins and environmental contaminants (e.g., Turja et al. 2014), and changes in community structure (e.g., biological invasions) that may alter the efficiency of cyanobacteria incorporation in the food webs (Karlson et al. 2014). Integrating these factors would make a major contribution to understanding and managing cyanobacteria and ecosystem productivity in the Baltic Sea.

\section{Managing eutrophication without reducing secondary and fish production}

To decrease eutrophication and cyanobacteria blooms, large efforts are being made to reduce $\mathrm{P}$ and $\mathrm{N}$ inputs into the Baltic Sea (Gustafsson et al. 2012). They have already resulted in nutrient declines in some local areas of the Baltic Sea (Elmgren and Larsson 2001), and bioavailable winter concentrations of $\mathrm{N}$ have also decreased somewhat in the open Baltic Proper, albeit not necessarily because of the decrease in loads. However, no systematic analysis of the consequences of these reductions and the changed nutrient ratios for secondary productivity in the coastal and open-sea food webs has been undertaken so far. While the spring bloom is N-limited, the cyanobacterial summer bloom appears to be P-limited (Granéli et al. 1990). Therefore, the effects of nutrient management can differ depending on the relative extent of $\mathrm{N}$ or P reduction. Reduced $\mathrm{N}$ loads are more likely to limit the organic load to sediments by reducing the spring bloom (Gustafsson et al. 2012) and, hence, the bottom hypoxia, but also benthic production. Reduced P load would decrease the summer production of cyanobacteria and probably also the other phytoplankton relying on the supply of diazotrophic $\mathrm{N}$ and, consequently, secondary production during summer, leading to decreasing fish production (Hansson et al. 2007). To understand and predict food web responses to our current and possible future management actions toward eutrophication and fishery (such as bottom water re-oxygenation, chemical P-precipitation, removal of zooplanktivorous fish, and other ecosystem-scale manipulations), we must recognize that cyanobacteria are one of many natural components of this ecosystem. They need to be understood in relation to other primary and secondary producers, including fish. Models are valuable tools for testing and improving our understanding at this level of ecosystem function (e.g., Savchuk and Wulff 1999; Hansson et al. 2007; Niiranen et al. 2013), and there is a great need for measurements and observations that help improve such models. It will be important to couple the ongoing efforts to manage nutrients and fishing in the Baltic Sea to resulting changes in fish feeding conditions, if we are to understand implications of our actions for the productivity of pelagic and benthic communities that governs fish production.

Acknowledgments Funding was provided by the Baltic Ecosystem Adaptive Management program of Stockholm University, The Swedish Research Council Formas (contracts 217-2007-749 to EG, 215-2009-813 to RE and 215-2010-779 to HP), The Swedish Environmental Protection Agency (contract holder Ulf Larsson, contracts 13/346, 2121150 and 212 1057), Sydvästra stockholmsregionens vaverksbolag, and the EU Sixth Framework Program SPICOSA. We thank Prof. Vidmantas Remeikis (Center for Physical Sciences and Technology, Vilnius, Lithuania) for IRMS equipment, Nurun Nahar, Johanna Bergkvist, Björn Andersson (Gothenburg University, Sweden), Rehab El-Shehawy (IMDEA-Water, Spain), Johan Gelting, Örjan Gustafsson, Johan Näslund, Francisco J.A. Nascimento, Helena Höglander, and Sture Hansson (Stockholm University) for unpublished data and fruitful discussions.

Open Access This article is distributed under the terms of the Creative Commons Attribution 4.0 International License (http:// creativecommons.org/licenses/by/4.0/), which permits unrestricted use, distribution, and reproduction in any medium, provided you give appropriate credit to the original author(s) and the source, provide a link to the Creative Commons license, and indicate if changes were made.

\section{REFERENCES}

Ahlgren, G., I.B. Gustafsson, and M. Boberg. 1992. Fatty acid content and chemical composition of freshwater microalgae. Journal of Phycology 28: 37-50.

Arrhenius, F., and S. Hansson. 1993. Food consumption of larval, young and adult herring and sprat in the Baltic Sea. Marine Ecology Progress Series 96: 125-137.

Basen, T., K.-O. Rothhaupt, and D. Martin-Creuzburg. 2012. Absence of sterols constrains food quality of cyanobacteria for an invasive freshwater bivalve. Oecologia 170: 57-64.

Basen, T., R. Gergs, K.-O. Rothhaupt, and D. Martin-Creuzburg. 2013. Phytoplankton food quality effects on gammarids: Benthic-pelagic coupling mediated by an invasive freshwater clam. Canadian Journal of Fisheries and Aquatic Sciences 70: 198-207.

Berglund, J., U. Müren, U. Båmstedt, and A. Andersson. 2007. Efficiency of a phytoplankton-based and a bacteria-based food web in a pelagic marine system. Limnology and Oceanography 52: 121-131.

Bianchi, T.S., P. Westman, C. Rolff, E. Engelhaupt, T. Andrén, and R. Elmgren. 2000. Cyanobacterial blooms in the Baltic Sea: Natural or human-induced? Limnology and Oceanography 45: 716-726.

Bianchi, T.S., C. Rolff, B. Widbom, and R. Elmgren. 2002. Phytoplankton pigments in Baltic Sea seston and sediments: Seasonal variability, fluxes, and transformations. Estuarine, Coastal and Shelf Science 55: 369-383.

Conley, D.J., J. Carstensen, J. Aigars, P. Axe, E. Bonsdorff, B.M. Eremina, T. Haati, C. Humborg, et al. 2011. Hypoxia is increasing in the coastal zone of the Baltic Sea. Environmental Science and Technology 45: 6777-6783.

Dorado, S., J.R. Rooker, B. Wissel, and A. Quigg. 2012. Isotope baseline shifts in pelagic food webs of the Gulf of Mexico. Marine Ecology Progress Series 464: 37-49. 
Elmgren, R., and U. Larsson. 2001. Nitrogen and the Baltic Sea: Managing nitrogen in relation to phosphorus. The Scientific World 1: 371-377.

El-Shehawy, R., E. Gorokhova, F. Fernández-Piñas, and F. Del Campo. 2012. Global warming and hepatotoxin production by cyanobacteria: What can we learn from experiments? Water Research 46: 1420-1429.

Engström, J., M. Koski, M. Viitasalo, M. Reinikainen, S. Repka, and K. Sivonen. 2000. Feeding interactions of Eurytemora affinis and Acartia bifilosa with toxic and non-toxic Nodularia sp. Journal of Plankton Research 22: 1403-1409.

Engström, J., M. Viherluoto, and M. Viitasalo. 2001. Effects of toxic and non-toxic cyanobacteria on grazing, zooplanktivory and survival of the mysid shrimp Mysis mixta. Journal of Experimental Marine Biology and Ecology 257: 269-280.

Engström-Öst, J., H. Hogfors, R. El-Shehawy, B. De Stasio, A. Vehmaa, and E. Gorokhova. 2011. Toxin producing cyanobacterium Nodularia spumigena, potential competitors and grazers: Testing mechanisms of reciprocal interactions in mixed plankton communities. Aquatic Microbial Ecology 62: 39-48.

Gergs, R., N. Steinberger, T. Basen, and D. Martin-Creuzburg. 2014. Dietary supply with essential lipids affects growth and survival of the amphipod Gammarus roeseli. Limnologica 46: 109-115.

Gorokhova, E. 2009. Toxic cyanobacteria Nodularia spumigena in the diet of Baltic mysids: Evidence from molecular diet analysis. Harmful Algae 8: 264-272.

Gorokhova, E., and J. Engström-Öst. 2009. Toxin concentration in Nodularia spumigena is modulated by mesozooplankton grazers. Journal of Plankton Research 31: 1235-1247.

Gorokhova, E., and M. Lehtiniemi. 2007. A combined approach to understand trophic interactions between Cercopagis pengoi (Cladocera: Onychopoda) and mysids in the Gulf of Finland. Limnology and Oceanography 52: 685-695.

Granéli, E., K. Wallström, U. Larsson, W. Granéli, and R. Elmgren. 1990. Nutrient limitation of primary production in the Baltic Sea area. AMBIO 19: 142-151.

Gulati, R.D., and W.R. DeMott. 1997. The role of food quality for zooplankton: Remarks on the state-of-the-art, perspectives and priorities. Freshwater Biology 38: 753-768.

Gunnars, A., and S. Blomqvist. 1997. Phosphate exchange across the sediment-water interface when shifting from anoxic to oxic conditions-an experimental comparison of freshwater and brackish-marine systems. Biogeochemistry 37: 203-226.

Gustafsson, B.G., F. Schenk, T. Blenckner, K. Eilola, H.E.M. Meier, B. Müller-Karulis, T. Neumann, T. Ruoho-Airola, et al. 2012. Reconstructing the development of Baltic Sea eutrophication 1850-2006. AMBIO 41: 534-548.

Gustafsson, Ö., J. Gelting, P. Andersson, U. Larsson, and P. Roos. 2013. An assessment of upper ocean carbon and nitrogen export fluxes on the boreal continental shelf: A 3-year study in the open Baltic Sea comparing sediment traps, ${ }^{234} \mathrm{Th}$ proxy, nutrient, and oxygen budgets. Limnology and Oceanography Methods 11: 495-510.

Hajdu, S., H. Höglander, and U. Larsson. 2007. Phytoplankton vertical distributions and composition in Baltic Sea cyanobacterial blooms. Harmful Algae 6: 189-205.

Hansen, J.P., S.A. Wikström, and L. Kautsky. 2012. Taxon composition and food web structure in a morphometric gradient of Baltic Sea land-uplift bays. Boreal Environment Research 17: $1-20$.

Hansson, S., J.E. Hobbie, R. Elmgren, U. Larsson, B. Fry, and S. Johansson. 1997. The stable nitrogen isotope ratio as a marker of food-web interactions and fish migration. Ecology 78: 2249-2257.

Hansson, S., O. Hjerne, C. Harvey, J.F. Kitchell, S.P. Cox, and T.E. Essington. 2007. Managing Baltic Sea fisheries under contrasting production and predation regimes: ecosystem model analyses. AMBIO 36: 265-271.

Hogfors, H., T. Holmborn, S. Hajdu, and E. Gorokhova. 2011. Does female RNA content reflect viable egg production in copepods? A test with the Baltic copepod Acartia tonsa. Journal of Plankton Research 33: 1460-1463.

Hogfors, H., N.H. Motwani, S. Hajdu, R. El-Shehawy, T. Holmborn, A. Vehmaa, J. Engström-Öst, A. Brutemark, et al. 2014. Bloomforming cyanobacteria support copepod reproduction and development in the Baltic Sea. PLoS ONE 9: e112692.

Holliland, P., T. Holmborn, and E. Gorokhova. 2012. Assessing diet of the predatory cladoceran Cercopagis pengoi using stable isotopes. Journal of Plankton Research 34: 376-387.

Hoppe, H.G. 1981. Blue-green algae agglomeration in surface water: A microbiotope of high bacterial activity. Kieler Meeresforsch Sonderheft 5: 291-303.

Kahru, M., and R. Elmgren. 2014. Multi-decadal time series of satellite-detected accumulations of cyanobacteria in the Baltic Sea. Biogeosciences 11: 3619-3633.

Kankaanpää, H.T., O. Sjövall, M. Huttunen, M. Olin, K. Karlsson, K. Hyvärinen, L. Sneitz, J. Harkonen, et al. 2009. Production and sedimentation of peptide toxins nodularin-R and microcystin-LR in the northern Baltic Sea. Environmental Pollution 157: 1301-1309.

Karjalainen, M., B. Kozlowsky-Suzuki, M. Lehtiniemi, J. EngströmÖst, H. Kankaanpää, and M. Viitasalo. 2006. Nodularin accumulation during cyanobacterial blooms and experimental depuration in zooplankton. Marine Biology 148: 683-691.

Karjalainen, M., J. Engström-Öst, S. Korpinen, H. Peltonen, J.-P. Pääkkönen, J.S. Rönkkönen, S. Suikkanen, and M. Viitasalo. 2007. Ecosystem consequences of cyanobacteria in the northern Baltic Sea. AMBIO 36: 195-202.

Karlson, A.M.L., and R. Mozuraitis. 2011. Deposit-feeders accumulate the cyanobacterial toxin nodularin. Harmful Algae 12: 77-81.

Karlson, A.M.L., F.J.A. Nascimento, and R. Elmgren. 2008. Incorporation and burial of carbon from settling cyanobacterial blooms by deposit-feeding macrofauna. Limnology and Oceanography 53: 2754-2758.

Karlson, A.M.L., F.J.A. Nascimento, J. Näslund, and R. Elmgren. 2010. Higher diversity of deposit-feeding macrofauna enhances phytodetritus processing in sediments. Ecology 91: 1414-1423.

Karlson, A.M.L., F.J.A. Nascimento, S. Suikkanen, and R. Elmgren. 2012. Benthic fauna affects recruitment from sediments of the harmful cyanobacterium Nodularia spumigena. Harmful Algae 20: $126-131$.

Karlson, A.M.L., E. Gorokhova, and R. Elmgren. 2014. Nitrogen fixed by cyanobacteria is utilized by deposit-feeders. PLOS ONE 9: e104460.

Koski, M., K. Schmidt, J. Engstrom-Öst, M. Viitasalo, S. Jonasdottir, S. Repka, and K. Sivonen. 2002. Calanoid copepods feed and produce eggs in the presence of toxic cyanobacteria Nodularia spumigena. Limnology and Oceanography 47: 878-885.

Kozlowsky-Suzuki, B., M. Karjalainen, M. Lehtiniemi, J. EngströmÖst, M. Koski, and P. Carlsson. 2003. Feeding, reproduction and toxin accumulation by the copepods Acartia bifilosa and Eurytemora affinis in the presence of the toxic cyanobacterium Nodularia spumigena. Marine Ecology Progress Series 249: 237-249.

Larsson, U., S. Hajdu, J. Walve, and R. Elmgren. 2001. Estimating Baltic nitrogen fixation from the summer increase in upper mixed layer total nitrogen. Limnology and Oceanography 46: $811-820$

Layman, C.A., D.A. Arrington, C.G. Montana, and D.M. Post. 2007. Can stable isotope ratios provide for community-wide measures of trophic structure? Ecology 88: 42-48. 
Lesutiene, J., P.A. Bukaveckas, Z.R. Gasiunaite, R. Pilkaityte, and A. Razinkovas-Baziukas. 2014. Tracing the isotopic signal of a cyanobacteria bloom through the food web of a Baltic Sea coastal lagoon. Estuarine and Coastal Shelf Science 138: 47-56.

Loick-Wilde, N., J. Dutz, A. Miltner, M. Gehre, J.P. Montoya, and M. Voss. 2012. Incorporation of nitrogen from $\mathrm{N}_{2}$ fixation into amino acids of zooplankton. Limnology and Oceanography 57: 199-210.

Mazur-Marzec, H., A. Tyminska, J. Szafranek, and M. Plinski. 2007. Accumulation of nodularin in sediments, mussels, and fish from the Gulf of Gdansk, southern Baltic Sea. Environmental Toxicology 22: 101-111.

Mazur-Marzec, H., A. Torunska, M.J. Błonska, M. Moskot, M. Plinski, J. Jakobkiewicz-Banecka, and G. Wegrzyn. 2009. Biodegradation of nodularin and effect of the toxin on bacterial isolates from the Gulf of Gdansk. Water Research 43: 2801-2810.

Meyer-Harms, B., M. Reckermann, M. Voß, H. Siegmund, and B. von Bodungen. 1999. Food selection by calanoid copepods in the euphotic layer of the Gotland Sea (Baltic Proper) during mass occurrence of $\mathrm{N}_{2}$-fixing cyanobacteria. Marine Ecology Progress Series 191: 243-250.

Motwani, N. H. 2015. Trophic complexity of zooplankton-cyanobacteria interactions in the Baltic Sea: Insights from molecular diet analysis. PhD thesis, Stockholm University, Stockholm, Sweden.

Motwani, N.H., and E. Gorokhova. 2013. Mesozooplankton grazing on picocyanobacteria in the Baltic Sea as inferred from molecular diet analysis. PLOS ONE 8: e79230.

Nascimento, F.J.A., A.M.L. Karlson, and R. Elmgren. 2008. Settling blooms of filamentous cyanobacteria as food for meiofauna assemblages. Limnology and Oceanography 53: 2636-2643.

Nascimento, F.J.A., A.M.L. Karlson, J. Näslund, and E. Gorokhova. 2009. Settling cyanobacterial blooms do not improve growth conditions for soft bottom meiofauna. Journal of Experimental Marine Biology and Ecology 368: 138-146.

Niemi, A. 1979. Blue-green algal blooms and N:P ratios in the Baltic Sea. Acta Botanica Fennica 110: 57-61.

Niiranen, S., J. Yletyinen, M.T. Tomczak, T. Blenckner, O. Hjerne, B.R. MacKenzie, B. Müller-Karulis, T. Neumann, et al. 2013. Combined effects of global climate change and regional ecosystem drivers on an exploited marine food web. Global Change Biology 19: 3327-3342.

Nordström, M., K. Aarnio, and E. Bonsdorff. 2009. Temporal variability of a benthic food web: Patterns and processes in a low-diversity system. Marine Ecology Progress Series 378: 13-26.

Oberholster, P.J., A.-M. Botha, and T.E. Cloete. 2006. Use of molecular markers as indicators for winter zooplankton grazing on toxic benthic cyanobacteria colonies in an urban Colorado lake. Harmful Algae 5: 705-716.

Ohlendieck, U., A. Stuhr, and H. Siegmund. 2000. Nitrogen fixation by diazotrophic cyanobacteria in the Baltic Sea and transfer of the newly fixed nitrogen to picoplankton organisms. Journal of Marine Systems 25: 213-219.

Paerl, H.W., and R.S. Fulton. 2006. Ecology of harmful cyanobacteria. In Ecology of harmful marine algae, ed. E. Granéli, and J. Turner, 95-107. Berlin: Springer.

Pandey, U., and J. Pandey. 2009. Enhanced production of deltaaminolevulinic acid, bilipigments, and antioxidants from tropical algae of India. Biotechnology and Bioprocess Engineering 14: 316-321.

Perga, M.E., I. Domaizon, J. Guillard, V. Hamelet, and O. Anneville. 2013. Are cyanobacterial blooms trophic dead ends? Oecologia 172: 551-562.

Persson, K.-J., P. Stenroth, and C. Legrand. 2011. Effects of the filamentous cyanobacterium Nodularia on fitness and feeding behavior of young-of-the-year (YOY) Eurasian perch (Perca fluviatilis). Toxicon 57: 1033-1040.

Peters, J., J. Renz, J. van Beusekom, M. Boersma, and W. Hagen. 2006. Trophodynamics and seasonal cycle of the copepod Pseudocalanus acuspes in the Central Baltic Sea (Bornholm Basin): Evidence from lipid composition. Marine Biology 149: 1417-1429.

Ploug, H. 2008. Cyanobacterial surface blooms formed by Aphanizomenon sp. and Nodularia spumigena in the Baltic Sea: Smallscale fluxes, $\mathrm{pH}$, and oxygen microenvironments. Limnology and Oceanography 53: 914-921.

Ploug, H., B. Adam, N. Musat, T. Kalvelage, G. Lavik, D. WolfGladrow, and M.M.M. Kuypers. 2011. Carbon, nitrogen, and $\mathrm{O}_{2}$ fluxes associated with the cyanobacterium Nodularia spumigena in the Baltic Sea. The ISME Journal 5: 1549-1558.

Prasanna, R., A. Sood, P. Jaiswal, S. Nayak, V. Gupta, V. Chaudhary, M. Joshi, and C. Natarajan. 2010. Rediscovering cyanobacteria as valuable sources of bioactive compounds (review). Applied Biochemistry and Microbiology 46: 119-134.

Reinikainen, M., M. Ketola, and M. Walls. 1994. Effects of the concentration of toxic Microcystis aeruginosa and an alternative food on the survival of Daphnia pulex. Limnoloy and Oceanography 39: 424-432.

Rolff, C. 2000. Seasonal variations in delta C-13 and delta N-15 of size fractioned plankton at a coastal station in the northern Baltic proper. Marine Ecology Progress Series 203: 47-65.

Rolff, C., and R. Elmgren. 2000. Use of riverine organic matter in plankton food webs of the Baltic Sea. Marine Ecology Progress Series 197: 81-101.

Savchuk, O., and F. Wulff. 1999. Modelling regional and large-scale responses of Baltic Sea ecosystems to nutrient reductions. Hydrobiologia 393: 35-43.

Schmidt, K., and S.H. Jonasdóttir. 1997. Nutritional quality of two cyanobacteria: How rich is 'poor' food? Marine Ecology Progress Series 151: 1-10.

Schmidt, K., M. Koski, J. Engström-Öst, and A. Atkinson. 2002. Development of Baltic Sea zooplankton in the presence of a toxic cyanobacterium: A mesocosm approach. Journal of Plankton Research 24: 979-992.

Sellner, K. 1997. Physiology, ecology, and toxic properties of marine cyanobacteria blooms. Limnology and Oceanography 42: 1089-1104.

Sipiä, V.O., O. Sjövall, T. Valtonen, D.H. Barnaby, G.A. Codd, J.S. Metcalf, M. Kilpi, and J.A.O. Meriluoto. 2006. Analysis of nodularin-R in eider (Somateria mollissima), roach (Rutilus rutilus L.) and flounder (Platichthys flesus L.) liver and muscle samples from the western Gulf of Finland, northern Baltic Sea. Environmental Toxicology and Chemistry 25: 2834-2839.

Sivonen, K., and G. Jones. 1999. Cyanobacterial toxins. In Toxic cyanobacteria in water: A guide to their public health consequences, monitoring and management, ed. I. Chorus, and J. Bartram, 41-111. London: E and FN Spon.

Sommer, F., T. Hansen, and U. Sommer. 2006. Transfer of diazotrophic nitrogen to mesozooplankton in Kiel Fjord, Western Baltic Sea: a mesocosm study. Marine Ecology Progress Series 32: 105-112.

Sotton, B., J. Guillard, O. Anneville, M. Maréchal, O. Savichtcheva, and I. Domaizon. 2014. Trophic transfer of microcystins through the lake pelagic food web: Evidence for the role of zooplankton as a vector in fish contamination. Science of the Total Environment 466-467: 152-163.

Stal, L.J., P. Albertano, B. Bergman, K. Brockeld, J.R. Gallone, P.K. Hayes, K. Sivonen, and A.E. Walsby. 2003. BASIC: Baltic Sea cyanobacteria. An investigation of the structure and dynamics of water blooms of cyanobacteria in the Baltic Sea-responses to a 
changing environment. Continental Shelf Research 23: $1695-1714$.

Suikkanen, S., H. Kaartokallio, S. Hällfors, M. Huttunen, and M. Laamanen. 2010. Life cycle strategies of bloom-forming, filamentous cyanobacteria in the Baltic Sea. Deep-Sea Research II 57: 199-209.

Svensen, C., E. Strogyloudi, C.W. Riser, J. Dahmann, C. Legrand, P. Wassmann, E. Graneli, and K. Pagou. 2005. Reduction of cyanobacterial toxins through coprophagy in Mytilus edulis. Harmful Algae 4: 329-336.

Tallberg, P., and A.S. Heiskanen. 1998. Species-specific phytoplankton sedimentation in relation to primary production along an inshore-offshore gradient in the Baltic Sea. Journal of Plankton Research 20: 2053-2070.

Tillmanns, A.R., A.E. Wilson, F.R. Pick, and O. Sarnelle. 2008. Meta-analysis of cyanobacterial effects on zooplankton population growth rate: Species-specific responses. Fundamental and Applied Limnology 171: 285-295.

Turja, R., L. Guimarães, A. Nevala, H. Kankaanpää, S. Korpinen, and K.K. Lehtonen. 2014. Cumulative effects of exposure to cyanobacteria bloom extracts and benzo[a]pyrene on antioxidant defence biomarkers in Gammarus oceanicus (Crustacea: Amphipoda). Toxicon 78: 68-77.

Uitto, A., and J. Sarvala. 1991. Seasonal growth of the benthic amphipods Pontoporeia affinis and P. femorata in a Baltic archipelago in relation to environmental factors. Marine Biology 111: 237-246.

Vehmaa, A., H. Hogfors, E. Gorokhova, A. Brutemark, T. Holmborn, and J. Engström-Öst. 2013. Projected marine climate change: effects on copepod oxidative status and reproduction. Ecology and Evolution. 3: 4548-4557.

Walve, J., and U. Larsson. 2007. Blooms of Baltic Sea Aphanizomenon sp. (Cyanobacteria) collapse after internal phosphorus depletion. Aquatic Microbial Ecology 49: 57-69.

Wannicke, N., F. Korth, I. Liskow, and M. Voss. 2013. Incorporation of diazotrophic fixed $\mathrm{N}_{2}$ by mesozooplankton-Case studies in the southern Baltic Sea. Journal of Marine Systems 117-118: $1-13$.

Wasmund, N. 1997. Occurrence of cyanobacterial blooms in the Baltic Sea in relation to environmental conditions. Internationale Revue der gesamten Hydrobiologie und Hydrographie 82: 169-184.

Wasmund, N., M. Voss, and K. Lochte. 2001. Evidence of nitrogen fixation by non-heterocystous cyanobacteria in the Baltic Sea and re-calculation of a budget of nitrogen fixation. Marine Ecology Progress Series 214: 1-14.

Wiklund, A.-K.E., B. Sundelin, and R. Rosa. 2008. Population decline of amphipod Monoporeia affinis in Northern Europe: Consequence of food shortage and competition? Journal of Experimental Marine Biology and Ecology 367: 81-90.

Woodland, R.J., D.P. Holland, J. Beardall, J. Smith, T. Scicluna, and P.L.M. Cook. 2013. Assimilation of diazotrophic nitrogen into pelagic food webs. PLOS ONE 8: e67588.

\section{AUTHOR BIOGRAPHIES}

Agnes M. L. Karlson $(\varangle)$ is a researcher. Her research focus is on benthic ecology, food web interactions, and stable isotopes as environmental tracers.

Address: Department of Environmental Science and Analytical Chemistry, Stockholm University, 10691 Stockholm, Sweden.

e-mail: agnes.karlson@aces.su.se
Jon Duberg is a doctoral candidate. His field is stable isotope ecology and cyanobacteria trophic linkages in the Baltic Sea.

Address: Department of Environmental Science and Analytical Chemistry, Stockholm University, 10691 Stockholm, Sweden.

e-mail: jon.duberg@aces.su.se

Nisha H. Motwani is a doctoral candidate. She is using molecular approaches to study zooplankton grazing.

Address: Department of Ecology, Environment and Plant Sciences, Stockholm University, 10691 Stockholm, Sweden.

e-mail: nisha.motwani@su.se

Hedvig Hogfors is a researcher. Her research interests include food web ecology and trophic interactions, with particular emphasis on cyanobacteria effects on zooplankton fitness.

Address: AquaBiota Water Research, Löjtnantsgatan 25,

11550 Stockholm, Sweden.

e-mail: hedvig.hogfors@aquabiota.se

Isabell Klawonn is a doctoral candidate. Her research field is carbon and nitrogen cycle in the ocean.

Address: Department of Ecology, Environment and Plant Sciences, Stockholm University, 10691 Stockholm, Sweden.

e-mail: isabell.klawonn@su.se

Helle Ploug is a Professor. Her research interests include carbon and nitrogen cycle in the ocean.

Address: Department of Biology and Environmental Sciences, University of Gothenburg, Box 461, 40530 Gothenburg, Sweden. e-mail: helle.ploug@bioenv.gu.se

Jennie Barthel Svedén is a doctoral candidate. Her research field is Baltic Sea cyanobacteria and marine nitrogen cycling.

Address: Department of Ecology, Environment and Plant Sciences, Stockholm University, 10691 Stockholm, Sweden.

e-mail: jennie.sveden@su.se

Andrius Garbaras is a researcher developing various applications of isotope ratio mass spectrometry.

Address: Mass Spectrometry Laboratory, Center for Physical Sciences and Technology, Savanoriu 231, 02300 Vilnius, Lithuania. e-mail: garbaras@ar.fi.lt

Brita Sundelin is an Associate Professor, working on effects of contaminants and other environmental stressors on amphipod reproduction.

Address: Department of Environmental Science and Analytical Chemistry, Stockholm University, 10691 Stockholm, Sweden.

e-mail: brita.sundelin@aces.su.se

Susanna Hajdu is a researcher. Her research interests include phytoplankton ecology and harmful algal blooms.

Address: Department of Ecology, Environment and Plant Sciences, Stockholm University, 10691 Stockholm, Sweden.

e-mail: susanna.hajdu@su.se

Ulf Larsson is an Associate Professor, and interested in Baltic pelagic ecosystems, eutrophication, and adaptive management. Address: Department of Ecology, Environment and Plant Sciences, Stockholm University, 10691 Stockholm, Sweden. e-mail: ulf.larsson@su.se 
Ragnar Elmgren is a Professor emeritus, and interested in Baltic Sea benthic ecology, eutrophication, and cyanobacteria.

Address: Department of Ecology, Environment and Plant Sciences, Stockholm University, 10691 Stockholm, Sweden.

e-mail: ragnar.elmgren@su.se
Elena Gorokhova is a Professor. Fields of interest include molecular ecology and adaptations to environmental changes.

Address: Department of Environmental Science and Analytical Chemistry, Stockholm University, 10691 Stockholm, Sweden.

e-mail: elena.gorokhova@aces.su.se 